
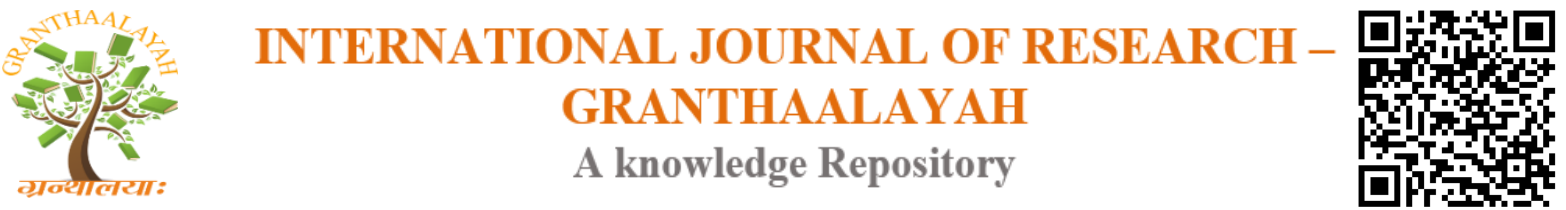

Science

\title{
USING WATER INDICES (NDWI, MNDWI, NDMI, WRI AND AWEI) TO DETECT PHYSICAL AND CHEMICAL PARAMETERS BY APPLY REMOTE SENSING AND GIS TECHNIQUES
}

\author{
Dr. Mustafa T. Mustafa ${ }^{* 1}$, Dr. Khalid I. Hassoon ${ }^{2}$, Dr. Hussain M. Hussain ${ }^{3}$, Modher H. \\ Abd ${ }^{4}$ \\ ${ }^{* 1}$ Head of building and construction engineering department, College Technical engineering, Iraq \\ ${ }^{2}$ Remote sensing Center, Directorate of space Technology and Communications, Ministry of \\ Science \&Technology, Iraq \\ ${ }^{3}$ Remote Sensing Center- University of Kufa, Iraq \\ ${ }^{4}$ Surveying Technical Engineer, Iraq
}

\begin{abstract}
This study was undertaken by analyzing data from satellite image (Landsat-8 OLI) and geographical information system (GIS) to find the relationship between water parameters and water indices of spectral images. The main purpose of this research was to develop a model for the physical and chemical parameters of Gharraf stream in Iraq. The water parameters used in this study included: acidity (PH), Total Dissolved Solids (T.D.S), Alkalinity(ALK), Electrical Conductivity (E.C), Calcium(Ca), Chloride (CL), Sodium (Na), Sulfate (SO4), Potassium (k), Total suspended solid (T.S.S), Total Hardness (TH).Where the samples were taken to seventeen stations with two seasons and at the same time took a satellite image on 4/FEB, 11 / MAY.GIS techniques were used in the beginning to project the coordinates of seventeen stations along the stream in Landsat-8 satellite image for extract data. Then, these data are treated in SPSS software for purpose finding correlation and regression equations. Positive strong correlations between the reflectance of the satellite image and the water parameters in 4/FEB and 11/ MAY with five stations, helped to build six regression models. These models could be used to predict these six water parameters (PH, E.c, CL, SO4, $\mathrm{Na}$ and $\mathrm{K}$ ) at any point along the stream in Iraq from the satellite image directly.
\end{abstract}

Keywords: Parameters Model; Al-Gharraf Stream; GIS, Remote Sensing; Landsat-8 OLI; Water Indices.

Cite This Article: Dr. Mustafa T. Mustafa, Dr. Khalid I. Hassoon, Dr. Hussain M. Hussain, and Modher H. Abd. (2017). "USING WATER INDICES (NDWI, MNDWI, NDMI, WRI AND AWEI) TO DETECT PHYSICAL AND CHEMICAL PARAMETERS BY APPLY REMOTE SENSING AND GIS TECHNIQUES." International Journal of Research - Granthaalayah, 5(10), 117-128. https://doi.org/10.29121/granthaalayah.v5.i10.2017.2289. 


\section{Introduction}

Gharraf stream is a necessary resource in thi qar city, especially for drinking and irrigation use. An increase of anthropogenic activities especially in the surrounding area near stream has effects to water bodies, where consider one of the most significant environmental issues in many areas of the world. Therefore, the stream water quality monitoring program is needed in order to raise sensibility of the public by address the consequences of present and future threats of contamination[1].the method in situ measurements of water quality characteristics is ordinarily limited, especially in spatial and temporal range, because of the high cost of data collection and laboratory analysis[2].in recent decades, the advent of increasingly efficient for satellite image (landsat-8 oli) analyses and geographical information system (gis) are significant tools to monitor and predict water quality parameters for rivers and stream[3].spectral indices are combinations of surface reflectance at two or more wavelengths[4]. These twelve parameters are acidity (ph), total dissolved solids (t.d.s), alkalinity(alk), electrical conductivity (e.c), calcium(ca), chloride (cl), sodium (na), sulfate (so4), potassium (k), total suspended solid (t.s.s), total hardness (th) from seventeen stations along the stream. Spectral indices are combinations of surface reflectance at two or more wavelengths. These indices were used in the present study: normalised -difference water index (ndwi), modification of normalised difference water index (mndwi), normalised difference moisture index (ndmi), water ratio index (wri) and automated water extraction index (awei), where these spectra were extracted from the image.

\section{Materials and Methods}

\subsection{Study Area}

The present study dealt with the Gharraf stream, which dates back to the Sumerian period (split King Antmina) of the Tigris River near the Dam of Kut. Gharraf stream is the longest branches of the Tigris River and derives its properties from it, Where the population in the areas that pass through the stream (998.729). In addition, the amount of drinking water in these areas is estimated at $6429 \mathrm{~m}^{3}$ and the cultivated land is estimated at (2151019) acres [5]. It's passing Wasit, Thi-Qar governorates, and ends in the marshes and the length of (230) $\mathrm{m}$ leading to Hammar south of Nasiriya City. Nasiriya is located between latitude $\left(30^{\circ} 36^{\prime} 00^{\prime \prime}\right.$ _ $\left.32^{\circ} 00^{\prime} 00^{\prime \prime} \mathrm{N}\right)$ and longitude $\left(45^{\circ} 36^{\prime} 00^{\prime \prime}\right.$ _ $\left.47^{\circ} 12^{\prime} 00^{\prime \prime} \mathrm{E}\right)$, as shown Figure (1). Stream extends towards the city, which is passes ALfagr, Gala Sikar, Al Rifai and Al Nasr and the (168 km) distance from the beginning branches of the river into two branches Shatt al-Shatra, which passes in Shatrah, Gharraf and ends in the marshes leading to Hammar, while the second section is the Shatt Al bdai, which ends in the marsh leading to Hammar also.

\subsection{In Situ Water Quality Data}

Water samples were collected from various spatial locations in the Gharraf stream on dates coinciding with Landsat-8 OLI acquisition dates (Table 1) of the study area for 20017. In addition, the physical and chemical parameters for seventeen stations with 4/FEB/, 11/MAY were analysis from the Department of the Environment Water / Najaf Governorate (Table 2 and $3)$. 


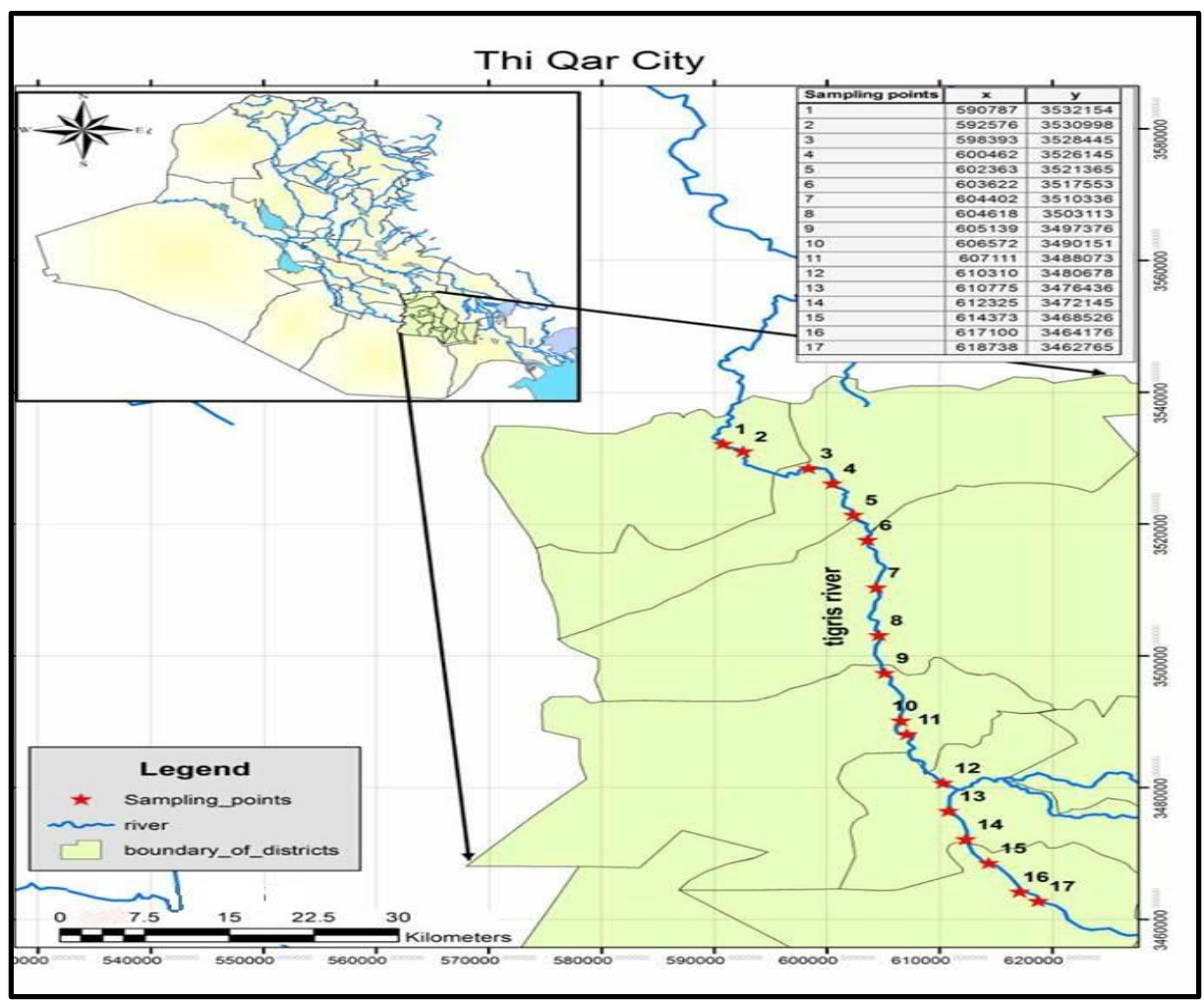

Figure 1: Location of the study area (Al- Gharraf stream)

Table 1: Details of Landsat -8 Data and in Situ Water Quality Sampling Dates.

\begin{tabular}{|l|l|l|l|l|}
\hline Year & $\begin{array}{l}\text { Water sample } \\
\text { Data }\end{array}$ & $\begin{array}{l}\text { Image acquisition } \\
\text { data }\end{array}$ & Path/Row & $\begin{array}{l}\text { Number of water sampling } \\
\text { points }\end{array}$ \\
\hline $\mathbf{2 0 1 7}$ & 4/FEB & 4/FEB & $168 / 38$ & 17 \\
\hline $\mathbf{2 0 1 7}$ & 11/MAY & 11/MAY & $168 / 38$ & 17 \\
\hline
\end{tabular}

Table2: Test results conducted in the Department of the Environment Water / Najaf Governorate (date: 4/FEB/2017).

\begin{tabular}{|c|c|c|c|c|c|c|c|c|c|c|c|c|c|c|}
\hline & \multirow[b]{2}{*}{ Name } & \multicolumn{2}{|c|}{ Location } & \multicolumn{4}{|c|}{ Physical Properties } & \multicolumn{4}{|c|}{ CatIon (mg/l) } & \multicolumn{3}{|c|}{ Anion $(\mathrm{mg} / \mathrm{l})$} \\
\hline & & $\mathbf{E}$ & $\mathbf{N}$ & $\mathbf{P h}$ & $\mathrm{EC}(\mu \mathrm{s} / \mathrm{cm})$ & TSS & TDS & $\mathbf{C a}$ & TH & $\mathrm{Na}$ & $\mathbf{K}$ & Cl & So4 & ALK \\
\hline Loc_01 & ALfagr & 590787 & 3532154 & 7.85 & 1494 & 60 & 1016 & 121 & 486 & 142.8 & 4.0 & 153 & 413 & 128 \\
\hline Loc_02 & ALfagr & 592576 & 3530998 & 8.01 & 1568 & 44 & 1022 & 127 & 508 & 146.0 & 4.4 & 148 & 281 & 136 \\
\hline Loc_03 & ALfagr & 598393 & 3528445 & 8.18 & 1471 & 30 & 1018 & 120 & 482 & 143.2 & 4.0 & 146 & 405 & 128 \\
\hline Loc_04 & Gala sgar & 600462 & 3526145 & 8.24 & 1477 & 58 & 1020 & 120 & 482 & 142.4 & 4.0 & 148 & 408 & 128 \\
\hline Loc_05 & Gala sgar & 602363 & 3521365 & 8.25 & 1476 & 60 & 1026 & 120 & 482 & 145.2 & 4.0 & 140 & 386 & 128 \\
\hline Loc_06 & Gala sgar & 603622 & 3517553 & 8.31 & 1474 & 36 & 1030 & 120 & 482 & 146.4 & 4.0 & 143 & 395 & 128 \\
\hline Loc_07 & Al-Rifai & 604402 & 3510336 & 8.31 & 1472 & 70 & 1032 & 120 & 482 & 144.8 & 4.0 & 144 & 392 & 126 \\
\hline Loc_08 & Al-Rifai & 604618 & 3503113 & 8.39 & 1467 & 42 & 1036 & 120 & 482 & 145.2 & 4.0 & 146 & 497 & 126 \\
\hline Loc_09 & Al-Rifai & 605139 & 3497376 & 8.43 & 1497 & 22 & 1026 & 121 & 486 & 142.0 & 4.0 & 144 & 397 & 128 \\
\hline Loc_10 & Alnsar & 606572 & 3490151 & 8.40 & 1480 & 56 & 1030 & 121 & 486 & 145.2 & 4.0 & 140 & 374 & 128 \\
\hline Loc_11 & Alnsar & 607111 & 3488073 & 8.42 & 1480 & 72 & 1028 & 121 & 486 & 143.2 & 4.0 & 143 & 404 & 128 \\
\hline Loc_12 & Albdai & 610310 & 3480678 & 8.42 & 1478 & 66 & 1024 & 120 & 482 & 144.4 & 4.0 & 144 & 408 & 128 \\
\hline Loc_13 & Alshatra & 610775 & 3476436 & 8.43 & 1481 & 28 & 1022 & 120 & 482 & 145.2 & 4.0 & 153 & 408 & 128 \\
\hline
\end{tabular}


DOI: 10.5281/zenodo.1040209

\begin{tabular}{|c|c|c|c|c|c|c|c|c|c|c|c|c|c|c|}
\hline Loc_14 & Alshatra & 612325 & 3472145 & 8.58 & 1485 & 36 & 1018 & 120 & 482 & 144.8 & 4.0 & 149 & 413 & 128 \\
\hline Loc_15 & Alshatra & 614373 & 3468526 & 8.80 & 1484 & 28 & 1022 & 120 & 482 & 145.6 & 4.0 & 144 & 394 & 128 \\
\hline Loc_16 & Algarraf & 617100 & 3464176 & 8.67 & 1502 & 40 & 1036 & 121 & 486 & 145.2 & 4.0 & 149 & 398 & 130 \\
\hline Loc_17 & Algarraf & 618738 & 3462765 & 8.34 & 1532 & 56 & 1040 & 122 & 490 & 146.8 & 4.4 & 137 & 402 & 132 \\
\hline
\end{tabular}

Table3: Test results conducted in the Department of the Environment Water / Najaf Governorate (date: 11/MAY/2017).

\begin{tabular}{|c|c|c|c|c|c|c|c|c|c|c|c|c|c|c|}
\hline & \multirow{2}{*}{ Name } & \multicolumn{2}{|c|}{ Location } & \multicolumn{4}{|c|}{ Physical Properties } & \multicolumn{4}{|c|}{ Catlon (mg/l) } & \multicolumn{3}{|c|}{ Anion $(\mathrm{mg} / \mathrm{l})$} \\
\hline & & $E$ & $\mathrm{~N}$ & $\mathrm{Ph}$ & $\mathrm{EC}(\mu \mathrm{s} / \mathrm{cm})$ & TSS & TDS & $\mathrm{Ca}$ & $\mathrm{TH}$ & $\mathrm{Na}$ & $K$ & $\mathrm{Cl}$ & So4 & ALK \\
\hline Loc_01 & Alfagr & 590787 & 3532154 & 8.4 & 828 & 34 & 564 & 73 & 294 & 74.7 & 2.4 & 90 & 181 & 74 \\
\hline Loc_02 & ALfagr & 592576 & 3530998 & 8.4 & 790 & 58 & 446 & 72 & 290 & 73.5 & 2.1 & 88 & 186 & 72 \\
\hline Loc_03 & Alfagr & 598393 & 3528445 & 8.3 & 808 & 34 & 482 & 73 & 294 & 75.6 & 1.8 & 89 & 171 & 72 \\
\hline Loc_04 & Gala sgar & 600462 & 3526145 & 8.3 & 808 & 24 & 598 & 73 & 294 & 74.7 & 2.4 & 89 & 181 & 72 \\
\hline Loc_05 & Gala sgar & 602363 & 3521365 & 8.3 & 818 & 48 & 560 & 73 & 294 & 75.6 & 2.4 & 88 & 171 & 74 \\
\hline Loc_06 & Gala sgar & 603622 & 3517553 & 8.4 & 816 & 56 & 486 & 73 & 294 & 76.2 & 2.4 & 88 & 176 & 74 \\
\hline Loc_07 & Al-Rifai & 604402 & 3510336 & 8.5 & 836 & 52 & 598 & 76 & 304 & 77.7 & 2.4 & 98 & 217 & 76 \\
\hline Loc_08 & Al-Rifai & 604618 & 3503113 & 8.4 & 816 & 60 & 562 & 73 & 294 & 77.4 & 2.4 & 89 & 202 & 74 \\
\hline Loc_09 & Al-Rifai & 605139 & 3497376 & 8.4 & 816 & 38 & 556 & 73 & 294 & 76.8 & 2.4 & 89 & 204 & 74 \\
\hline Loc_10 & Alnsar & 606572 & 3490151 & 8.4 & 827 & 42 & 494 & 73 & 294 & 76.5 & 2.1 & 90 & 182 & 76 \\
\hline Loc_11 & Alnsar & 607111 & 3488073 & 8.3 & 851 & 68 & 488 & 76 & 304 & 78.0 & 2.1 & 94 & 208 & 76 \\
\hline Loc_12 & Albdai & 610310 & 3480678 & 8.6 & 848 & 38 & 680 & 76 & 304 & 79.5 & 2.4 & 92 & 246 & 76 \\
\hline Loc_13 & Alshatra & 610775 & 3476436 & 8.4 & 846 & 36 & 450 & 76 & 304 & 75.9 & 2.4 & 93 & 205 & 76 \\
\hline Loc_14 & Alshatra & 612325 & 3472145 & 8.4 & 855 & 40 & 646 & 76 & 304 & 76.5 & 2.4 & 94 & 214 & 76 \\
\hline Loc_15 & Alshatra & 614373 & 3468526 & 8.6 & 881 & 36 & 602 & 77 & 308 & 89.7 & 3.9 & 98 & 208 & 78 \\
\hline Loc_16 & Algarraf & 617100 & 3464176 & 8.5 & 866 & 54 & 526 & 77 & 308 & 79.2 & 2.4 & 100 & 214 & 78 \\
\hline Loc 17 & Algarraf & 618738 & 3462765 & 8.5 & 872 & 16 & 628 & 77 & 308 & 76.5 & 2.4 & 102 & 220 & 78 \\
\hline
\end{tabular}

\subsection{Remote Sensing Data}

In this study, Landsat 8 OLI imagery with a spatial resolution of $30 * 30 \mathrm{~m}$ in the optical bands was downloaded from the United States Geological Survey (USGS) Earth Explorer website (www.earthexplorer.usgs.gov). A total of two Landsat images (path 168, row 30) acquired on 04 FEB and 11 MAY in 2017 were used in this study

The methodology consists of the following steps:

1) Conversion of satellite image digital number values to unitless planetary reflectance.

2) Atmospheric and geometric correction of the satellite image.(Landsat- 8 correct).

3) Application of water index.

4) Correlation and regression analysis between the pixel reflectance values and the water quality.

\subsubsection{Conversion of (DNS) to Top of Atmosphere Reflectance}

This conversion is important for studies regarding reflectance of river surfaces because the raw digital numbers of a Landsat-8 the image is not only dependent on the reflectance characteristics of the specific scene.in addition, its contain noise and digital number value offsets that are a result of the viewing geometry of the satellite, atmospheric depth due to viewing angle, the design characteristics of the sensor and the angle of the sun's incoming radiation [6]. Extracting 
the information from Landsat images, a single pixel (digital numbers, DN) was converted to reflectance according to following equation [7]:

$$
\rho \lambda^{\prime}=M^{p *} Q c a l+A^{p}
$$

Where:

$\rho \lambda^{\prime}=$ Top-of-Atmosphere Planetary Spectral Reflectance, without correction for solar angle. $\mathrm{M}^{\mathrm{p}}=$ Reflectance multiplicative scaling factor for the band (REFLECTANCEW MULT_BAND_n from the metadata).

$\mathrm{A}^{\mathrm{p}}=$ Reflectance additive scaling factor for the band (REFLECTANCE_ADD_BAND_N from the metadata).

Qcal = Level -1 pixel value in DN.

Note:

$\rho \lambda^{\prime}$ is not true TOA Reflectance because it does not contain a correction for the solar elevation angle. The conversion to true TOA Reflectance formula is:

$$
\mathrm{P} \lambda=\rho \lambda^{\prime} / \sin (\theta)
$$

Where:

$\mathrm{P} \lambda=$ Top-of-Atmosphere Planetary Reflectance.

$\theta=$ Solar Elevation Angle (from the metadata, or calculated).

The Reflectance values for each Landsat-8 OLI band for the water sampling location on each date were extracted, as shown Table (4 and 5).

\subsubsection{Atmospheric and Geometric Correction}

Landsat-8 OLI data for 0.07 clouds for scene. The images were precision corrected by geometric and radiometric.

Table 4: Satellite image reflectance values in bands 3-7 at seventeen different stations (date:

\begin{tabular}{|l|l|l|l|l|l|}
\hline & B3 & B4 & B5 & B6 & B7 \\
\hline Loc_01 & 0.1188 & 0.0841 & 0.0237 & 0.0105 & 0.0105 \\
\hline Loc_02 & 0.1196 & 0.0853 & 0.0254 & 0.0103 & 0.0091 \\
\hline Loc_03 & 0.1175 & 0.0811 & 0.0264 & 0.0161 & 0.0135 \\
\hline Loc_04 & 0.1215 & 0.0857 & 0.0256 & 0.0115 & 0.0115 \\
\hline Loc_05 & 0.1205 & 0.0844 & 0.0310 & 0.0177 & 0.0137 \\
\hline Loc_06 & 0.1202 & 0.0781 & 0.0134 & 0.0040 & 0.0003 \\
\hline Loc_07 & 0.1215 & 0.0813 & 0.0213 & 0.0010 & 0.0063 \\
\hline Loc_08 & 0.1209 & 0.0822 & 0.0267 & 0.0170 & 0.0185 \\
\hline
\end{tabular}




\begin{tabular}{|l|l|l|l|l|l|}
\hline Loc_09 & 0.1216 & 0.0834 & 0.0262 & 0.0160 & 0.0136 \\
\hline Loc_10 & 0.1260 & 0.0870 & 0.0269 & 0.0141 & 0.0139 \\
\hline Loc_11 & 0.1226 & 0.0855 & 0.0348 & 0.0150 & 0.0152 \\
\hline Loc_12 & 0.1241 & 0.0855 & 0.0295 & 0.0091 & 0.0139 \\
\hline Loc_13 & 0.1505 & 0.1471 & 0.1373 & 0.1408 & 0.1218 \\
\hline Loc_14 & 0.1250 & 0.1176 & 0.1530 & 0.0905 & 0.0789 \\
\hline Loc_15 & 0.1179 & 0.1203 & 0.1757 & 0.1789 & 0.1324 \\
\hline Loc_16 & 0.1045 & 0.0960 & 0.1148 & 0.0997 & 0.0818 \\
\hline Loc_17 & 0.1600 & 0.1732 & 0.2020 & 0.2158 & 0.2013 \\
\hline
\end{tabular}

B3=Green, B4=Red, B5=NIR, B6=SWIR1, B7=SWIR2

Table 5: Satellite image reflectance values in bands 3-7 at seventeen different stations (date: 11/MAY/2017).

\begin{tabular}{|l|l|l|l|l|l|}
\hline & B3 & B4 & B5 & B6 & B7 \\
\hline Loc_01 & 0.1617 & 0.1630 & 0.1297 & 0.0996 & 0.0710 \\
\hline Loc_02 & 0.1686 & 0.1714 & 0.1352 & 0.1023 & 0.0737 \\
\hline Loc_03 & 0.1642 & 0.1655 & 0.1355 & 0.1011 & 0.0713 \\
\hline Loc_04 & 0.1610 & 0.1622 & 0.1211 & 0.0903 & 0.0650 \\
\hline Loc_05 & 0.1576 & 0.1567 & 0.1305 & 0.0935 & 0.0640 \\
\hline Loc_06 & 0.1680 & 0.1678 & 0.1137 & 0.0835 & 0.0620 \\
\hline Loc_07 & 0.1665 & 0.1698 & 0.1218 & 0.0943 & 0.0714 \\
\hline Loc_08 & 0.1592 & 0.1593 & 0.1230 & 0.0839 & 0.0631 \\
\hline Loc_09 & 0.1493 & 0.1446 & 0.1671 & 0.0786 & 0.0506 \\
\hline Loc_10 & 0.1598 & 0.1559 & 0.0912 & 0.0669 & 0.0537 \\
\hline Loc_11 & 0.1509 & 0.1480 & 0.1396 & 0.0879 & 0.0560 \\
\hline Loc_12 & 0.1468 & 0.1422 & 0.1804 & 0.0916 & 0.0607 \\
\hline Loc_13 & 0.1907 & 0.2064 & 0.2089 & 0.1804 & 0.1563 \\
\hline Loc_14 & 0.1660 & 0.1705 & 0.2220 & 0.1949 & 0.1494 \\
\hline Loc_15 & 0.1688 & 0.1793 & 0.2670 & 0.1797 & 0.1274 \\
\hline Loc_16 & 0.1706 & 0.1815 & 0.2425 & 0.2019 & 0.1545 \\
\hline Loc_17 & 0.2107 & 0.2333 & 0.2783 & 0.2732 & 0.2362 \\
\hline
\end{tabular}

B3=Green, B4=Red, B5=NIR, B6=SWIR1, B7=SWIR2

This process is done using (Arc GIS 10.2).

\subsubsection{Application of Water Index}

After the geo-referenced image data should be converted into top-of-atmosphere (TOA) spectral reflectance using procedures detailed by the image metadata. All output files should be formatted as 32-bit. The water index is then calculated using Equations, as shown Table (6). 
Table 6: Water indices

\begin{tabular}{|c|c|c|}
\hline Index & Formula & Reference \\
\hline $\begin{array}{l}\text { Normalized Difference water } \text { Index } \\
\text { (NDWI) }\end{array}$ & $\mathrm{NDWI}=\frac{\mathrm{GREEN}-\mathrm{NIR}}{\mathrm{GREEN}+\mathrm{NIR}}$ & 8 \\
\hline $\begin{array}{l}\text { Modification Of Normalized Difference } \\
\text { Water Index (MNDWI) }\end{array}$ & MNDWI $=\frac{\text { GREEN-SWIR2 }}{\text { GREEN+SWIR2 }}$ & 9 \\
\hline $\begin{array}{l}\text { Normalized Difference Moisture Index } \\
\text { (NDMI) }\end{array}$ & $\mathrm{NDMI}=\frac{\mathrm{RED}-\mathrm{NIR}}{\mathrm{RED}+\mathrm{NIR}}$ & 10 \\
\hline $\begin{array}{lll}\text { Automated } & \text { Water } & \text { Extraction } \\
\text { Index(AWEI) } & & \end{array}$ & $\begin{array}{l}\text { AWEI }= \\
4 *(\text { GREEN-SWIR })- \\
\left(0.25^{*} \text { NIR+2.75*SWIR } 1\right)\end{array}$ & 11 \\
\hline Water Ratio Index(WRI) & $\mathrm{WRI}=\frac{\mathrm{GREEN}+\mathrm{RED}}{\mathrm{NIR}+\mathrm{SWIR} 2}$ & 12 \\
\hline
\end{tabular}

This process is done using (Arc GIS 10.2).

\subsubsection{Correlation and Regression Analysis}

To assess the nature and strength of the relationships, the reflectance index values of the image, that are the NDWI, MNDWI, NDMI, WRI, and AWEI were separately against eleven parameters. The coefficient of determination (R2) was used as a statistical measure of how successful the fitted regression model was in explaining the variation of the observed data. R2 values range from 0 to 1 , with values close to 1 indicating good model fit. A statistical analysis was performed on the extracted from Arc GIS 10.2 as excel data .Then, this data input to spss software for find the strength of the linear relationship between the two variables is the correlation coefficient(R), as shown Table $(7 \mathrm{a}, \mathrm{b})$ and Table (8a,b).in addition, application of regression equations Table $(9 a, b)$.

The seventeen stations were separated into two sets due to the two reaches of the stream, where the first twelve stations represented the first reach of the stream (50-60) m width. This reach was equivalent to 2 pixels of the satellite image, which these pixels could not mix only water. While, the five other stations represented the second reach of the stream (15-20) m width. This second reach was equivalent to less than one pixel due to the pixels were a mixture of water, vegetation and soil.

\section{Results and Discussion}

In this study, regression analysis was used to determine the physical and chemical parameters that were considered important explain water quality of Gharraf stream. Situ measurements and the satellite image acquisition time of the stream at seventeen stations at various parts of the stream were input into regression formulae. R Square values revealed that except for (E.c, ALK, T.H, Ca, T.D.s and T.S.S), very high accuracy will be obtained for (PH, CL,SO4, Na, and k) with five stations with date:4/FEB/2017 have respectively $0.752,0.918,0.982,0.915$ and $0.820 \mathrm{R}$ square values, while R Square values revealed that except for (ALK, T.H, Ca, T.D.s and T.S.S), very high accuracy will be obtained for (PH, E.c, CL, SO4, Na, and k) with five stations with date:11/MAY/2017 have respectively $0.904,0.983,0.712,0.999,0.974$ and 0.873 . 
The reflectance in water surface depends upon the sun elevation, where the sun elevation affects the amount of radiation received by the surface of the water, as shown Table (4) and Table (5). Sun elevation in 4 /FEB /2017 was $\left(36.32951258^{\circ}\right)$ and $11 / \mathrm{MAY} / 2017$ was $\left(66.52810785^{\circ}\right)$.

Using TOA reflectance with different features of the Landsat 8 OLI sensor obtained higher classification results compared to the TM and ETM+ sensors. This was because the Landsat 8 OLI sensor provides higher SNR imagery than the other sensors [9]. The reflectance five stations were mentioned earlier that the pixels are a mixture of water, vegetation (high due to leaf development and free water leaf) and soil (moisture content is low) that is caused increasing in reflectivity.

Finally, the reflectance in water surface depends upon the sky reflection, the color of the chemical contents disbanded in the water or plants and animals at the bottom of the stream.

\section{Conclusions}

Some physical and chemical parameters can be calculated using water index form Landsat-8 (OLI) images.

Table (7a): Pearson correlation between spectral water index and water parameters for 4/FEB/2017 with twelve stations

\begin{tabular}{|c|c|c|c|c|c|c|c|c|c|c|c|c|}
\hline & & $\mathrm{PH}$ & E.C & ALK & T.H & $\mathrm{Ca}$ & $\mathrm{CL}$ & $\mathrm{SO} 4$ & $\mathrm{Na}$ & $\mathrm{K}+$ & T.D.S & T.S.S \\
\hline \multirow[t]{3}{*}{ NDWI } & $\begin{array}{l}\text { Pearson } \\
\text { Correlation }\end{array}$ & -.150 & -.033 & -.051 & -.071 & -.066 & .123 & -.059 & .388 & -.002 & .158 & -.328 \\
\hline & Sig. (1tailed) & .320 & .459 & .438 & .414 & .420 & .351 & .428 & .106 & .497 & .312 & .149 \\
\hline & $\mathrm{N}$ & 12 & 12 & 12 & 12 & 12 & 12 & 12 & 12 & 12 & 12 & 12 \\
\hline \multirow[t]{3}{*}{ WRI } & $\begin{array}{l}\text { Pearson } \\
\text { Correlation }\end{array}$ & -.045 & -.064 & -.008 & -.086 & -.081 & -.062 & -.113 & .470 & -.018 & .192 & -.242 \\
\hline & Sig. (1tailed) & .444 & .422 & .491 & .396 & .401 & .424 & .364 & .062 & .477 & .275 & .224 \\
\hline & $\mathrm{N}$ & 12 & 12 & 12 & 12 & 12 & 12 & 12 & 12 & 12 & 12 & 12 \\
\hline \multirow[t]{3}{*}{ AWEI } & $\begin{array}{l}\text { Pearson } \\
\text { Correlation }\end{array}$ & -.017 & .020 & .033 & -.004 & .000 & -.076 & -.290 & .442 & .050 & .184 & .106 \\
\hline & Sig. (1tailed) & .479 & .476 & .459 & .495 & .500 & .407 & .180 & .075 & .439 & .283 & .372 \\
\hline & $\mathrm{N}$ & 12 & 12 & 12 & 12 & 12 & 12 & 12 & 12 & 12 & 12 & 12 \\
\hline \multirow[t]{3}{*}{ NDMI } & $\begin{array}{l}\text { Pearson } \\
\text { Correlation }\end{array}$ & -.215 & .021 & .007 & -.021 & -.016 & .169 & -.106 & .380 & .044 & .099 & -.322 \\
\hline & Sig. (1tailed) & .251 & .475 & .492 & .474 & .480 & .300 & .372 & .112 & .446 & .380 & .154 \\
\hline & $\mathrm{N}$ & 12 & 12 & 12 & 12 & 12 & 12 & 12 & 12 & 12 & 12 & 12 \\
\hline \multirow[t]{3}{*}{ MNDWI } & $\begin{array}{l}\text { Pearson } \\
\text { Correlation }\end{array}$ & -.209 & .116 & .147 & .077 & .082 & .020 & -.370 & .417 & .140 & .031 & -.071 \\
\hline & Sig. (1tailed) & .257 & .360 & .324 & .406 & .400 & .475 & .119 & .089 & .332 & .462 & .414 \\
\hline & $\mathrm{N}$ & 12 & 12 & 12 & 12 & 12 & 12 & 12 & 12 & 12 & 12 & 12 \\
\hline
\end{tabular}

**. Correlation is significant at the 0.01 level (1-tailed).*. Correlation is significant at the 0.05 level (1tailed). 
Table (7b): Pearson correlation between spectral water index and water parameters for 4/FEB/2017 with five stations

\begin{tabular}{|c|c|c|c|c|c|c|c|c|c|c|c|c|}
\hline & & $\mathrm{PH}$ & E.C & ALK & T.H & $\mathrm{Ca}$ & $\mathrm{CL}$ & $\mathrm{SO} 4$ & $\mathrm{Na}$ & $\mathrm{K}+$ & T.D.S & T.S.S \\
\hline \multirow[t]{3}{*}{ NDWI } & $\begin{array}{l}\text { Pearson } \\
\text { Correlation }\end{array}$ & -.503 & -.175 & -.093 & -.093 & -.093 & .670 & .491 & -.329 & -.205 & -.006 & -.154 \\
\hline & $\begin{array}{l}\text { Sig. } \\
\text { (1tailed) }\end{array}$ & .194 & .389 & .441 & .441 & .441 & .108 & .200 & .294 & .370 & .496 & .403 \\
\hline & $\mathrm{N}$ & 5 & 5 & 5 & 5 & 5 & 5 & 5 & 5 & 5 & 5 & 5 \\
\hline \multirow[t]{3}{*}{ WRI } & $\begin{array}{l}\text { Pearson } \\
\text { Correlation }\end{array}$ & -.274 & -.446 & -.383 & -.383 & -.383 & $.859^{*}$ & .691 & -.675 & -.484 & -.324 & -.340 \\
\hline & $\begin{array}{l}\text { Sig. } \\
\text { (1tailed) }\end{array}$ & .328 & .226 & .262 & .262 & .262 & .031 & .098 & .106 & .204 & .297 & .288 \\
\hline & $\mathrm{N}$ & 5 & 5 & 5 & 5 & 5 & 5 & 5 & 5 & 5 & 5 & 5 \\
\hline \multirow[t]{3}{*}{ AWEI } & $\begin{array}{l}\text { Pearson } \\
\text { Correlation }\end{array}$ & .271 & -.643 & -.593 & -.593 & -.593 & $.867^{*}$ & .527 & $.944^{* * *}$ & -.778 & -.512 & -.492 \\
\hline & $\begin{array}{l}\text { Sig. } \\
\text { (1tailed) }\end{array}$ & .330 & .121 & .146 & .146 & .146 & .029 & .181 & .008 & .061 & .189 & .200 \\
\hline & $\mathrm{N}$ & 5 & 5 & 5 & 5 & 5 & 5 & 5 & 5 & 5 & 5 & 5 \\
\hline \multirow[t]{3}{*}{ NDMI } & $\begin{array}{l}\text { Pearson } \\
\text { Correlation }\end{array}$ & -.717 & .034 & .093 & .093 & .093 & .410 & .429 & -.005 & .090 & .130 & .013 \\
\hline & $\begin{array}{l}\text { Sig. } \\
\text { (1tailed) }\end{array}$ & .087 & .479 & .441 & .441 & .441 & .246 & .236 & .497 & .443 & .418 & .491 \\
\hline & $\mathrm{N}$ & 5 & 5 & 5 & 5 & 5 & 5 & 5 & 5 & 5 & 5 & 5 \\
\hline \multirow[t]{3}{*}{ MNDWI } & $\begin{array}{l}\text { Pearson } \\
\text { Correlation }\end{array}$ & .139 & -.587 & -.552 & -.552 & -.552 & $.821^{*}$ & .664 & $.901-^{*}$ & -.684 & -.522 & -.409 \\
\hline & $\begin{array}{l}\text { Sig. } \\
\text { (1tailed) }\end{array}$ & .412 & .149 & .167 & .167 & .167 & .044 & .111 & .018 & .102 & .184 & .247 \\
\hline & $\mathrm{N}$ & 5 & 5 & 5 & 5 & 5 & 5 & 5 & 5 & 5 & 5 & 5 \\
\hline
\end{tabular}

**. Correlation is significant at the 0.01 level (1-tailed).*. Correlation is significant at the 0.05 level (1tailed).

Table (8a): Pearson correlation between spectral water index and water parameters for 11/MAY/2017 with twelve stations

\begin{tabular}{|c|c|c|c|c|c|c|c|c|c|c|c|c|}
\hline & & $\mathrm{PH}$ & E.C & ALK & T.H & $\mathrm{Ca}$ & $\mathrm{CL}$ & $\mathrm{SO} 4$ & $\mathrm{Na}$ & $\mathrm{K}+$ & T.D.S & T.S.S \\
\hline \multirow[t]{3}{*}{ NDWI } & $\begin{array}{l}\text { Pearson } \\
\text { Correlation }\end{array}$ & -.106 & .188 & .384 & -.028 & -.042 & -.128 & .011 & .304 & .078 & -.176 & .123 \\
\hline & $\begin{array}{l}\text { Sig. } \\
\text { (1tailed) }\end{array}$ & .372 & .280 & .109 & .465 & .448 & .346 & .487 & .168 & .404 & .292 & .352 \\
\hline & $\mathrm{N}$ & 12 & 12 & 12 & 12 & 12 & 12 & 12 & 12 & 12 & 12 & 12 \\
\hline \multirow[t]{3}{*}{ WRI } & $\begin{array}{l}\text { Pearson } \\
\text { Correlation }\end{array}$ & -.279 & -.237 & .016 & -.358 & -.364 & -.106 & .573 & -.327 & -.147 & -.468 & .112 \\
\hline & $\begin{array}{l}\text { Sig. } \\
\text { (1tailed) }\end{array}$ & .190 & .229 & .480 & .127 & .122 & .372 & .026 & .150 & .324 & .063 & .365 \\
\hline & $\mathrm{N}$ & 12 & 12 & 12 & 12 & 12 & 12 & 12 & 12 & 12 & 12 & 12 \\
\hline \multirow[t]{3}{*}{ AWEI } & $\begin{array}{l}\text { Pearson } \\
\text { Correlation }\end{array}$ & -.127 & -.015 & .284 & -.211 & -.225 & -.145 & -.234 & .087 & .049 & -.315 & .147 \\
\hline & $\begin{array}{l}\text { Sig. } \\
\text { (1tailed) }\end{array}$ & .347 & .482 & .186 & .255 & .241 & .326 & .232 & .394 & .439 & .160 & .324 \\
\hline & $\mathrm{N}$ & 12 & 12 & 12 & 12 & 12 & 12 & 12 & 12 & 12 & 12 & 12 \\
\hline \multirow[t]{3}{*}{ NDMI } & $\begin{array}{l}\text { Pearson } \\
\text { Correlation }\end{array}$ & -.324 & -.335 & -.131 & -.390 & -.393 & -.083 & .636 & -.460 & -.163 & -.472 & .109 \\
\hline & $\begin{array}{l}\text { Sig. } \\
\text { (1tailed) }\end{array}$ & .152 & .144 & .342 & .105 & .103 & .399 & .013 & .066 & .306 & .061 & .368 \\
\hline & $\mathrm{N}$ & 12 & 12 & 12 & 12 & 12 & 12 & 12 & 12 & 12 & 12 & 12 \\
\hline MNDWI & $\begin{array}{l}\text { Pearson } \\
\text { Correlation }\end{array}$ & -.106 & .188 & .384 & -.028 & -.042 & -.128 & .011 & .304 & .078 & -.176 & .123 \\
\hline
\end{tabular}




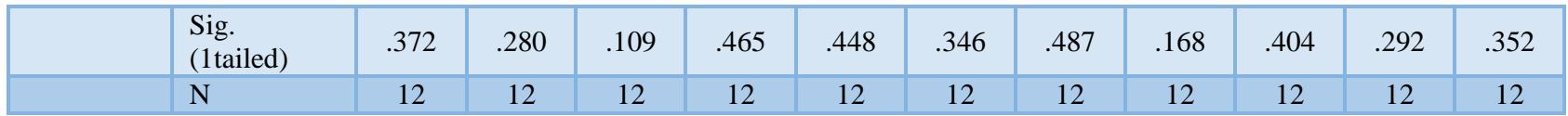

**. Correlation is significant at the 0.01 level (1-tailed).*. Correlation is significant at the 0.05 level (1tailed).

Table (8b): Pearson correlation between spectral water index and water parameters for 11/MAY/2017 with five stations

\begin{tabular}{|c|c|c|c|c|c|c|c|c|c|c|c|c|}
\hline & & $\mathrm{PH}$ & E.C & ALK & T.H & $\mathrm{Ca}$ & $\mathrm{CL}$ & $\mathrm{SO} 4$ & $\mathrm{Na}$ & $\mathrm{K}+$ & T.D.S & T.S.S \\
\hline \multirow[t]{3}{*}{ NDWI } & $\begin{array}{l}\text { Pearson } \\
\text { Correlation }\end{array}$ &. & . $874 *$ & $\begin{array}{c}- \\
0.704\end{array}$ & $\begin{array}{c}- \\
0.704\end{array}$ & $\begin{array}{c}- \\
0.704\end{array}$ & $\begin{array}{c}- \\
0.528\end{array}$ & $\begin{array}{c}- \\
0.246\end{array}$ & $\begin{array}{c}- \\
0.780\end{array}$ & $\begin{array}{c}- \\
0.679\end{array}$ & $\begin{array}{c}- \\
0.598\end{array}$ & $\begin{array}{c}- \\
0.184\end{array}$ \\
\hline & $\begin{array}{l}\text { Sig. } \\
\text { (1tailed) }\end{array}$ & 0.043 & 0.026 & 0.092 & 0.092 & 0.092 & 0.180 & 0.345 & 0.060 & 0.104 & 0.143 & 0.384 \\
\hline & $\mathrm{N}$ & 5 & 5 & 5 & 5 & 5 & 5 & 5 & 5 & 5 & 5 & 5 \\
\hline \multirow[t]{3}{*}{ WRI } & $\begin{array}{l}\text { Pearson } \\
\text { Correlation }\end{array}$ & $\begin{array}{c}- \\
0.604\end{array}$ & $\begin{array}{c}- \\
0.797\end{array}$ & $\begin{array}{c}- \\
0.711\end{array}$ & $\begin{array}{c}- \\
0.711\end{array}$ & $\begin{array}{c}- \\
0.711\end{array}$ & $\begin{array}{c}- \\
0.750\end{array}$ & $\begin{array}{c}- \\
0.734\end{array}$ & $\begin{array}{c}- \\
0.357\end{array}$ & $\begin{array}{c}- \\
0.259\end{array}$ & $\begin{array}{c}- \\
.808^{*}\end{array}$ & 0.095 \\
\hline & $\begin{array}{l}\text { Sig. } \\
\text { (1tailed) }\end{array}$ & 0.140 & 0.053 & 0.089 & 0.089 & 0.089 & 0.072 & 0.079 & 0.278 & 0.337 & 0.049 & 0.439 \\
\hline & $\mathrm{N}$ & 5 & 5 & 5 & 5 & 5 & 5 & 5 & 5 & 5 & 5 & 5 \\
\hline \multirow[t]{3}{*}{ AWEI } & $\begin{array}{l}\text { Pearson } \\
\text { Correlation }\end{array}$ & $\begin{array}{c}- \\
0.029\end{array}$ & $\begin{array}{c}- \\
0.262\end{array}$ & $\begin{array}{c}- \\
0.398\end{array}$ & $\begin{array}{c}- \\
0.398\end{array}$ & $\begin{array}{c}- \\
0.398\end{array}$ & $\begin{array}{c}- \\
0.707\end{array}$ &. & 0.428 & 0.434 & 0.452 & 0.651 \\
\hline & $\begin{array}{l}\text { Sig. } \\
\text { (1tailed) }\end{array}$ & 0.482 & 0.335 & 0.253 & 0.253 & 0.253 & 0.091 & 0.017 & 0.236 & 0.233 & 0.223 & 0.117 \\
\hline & $\mathrm{N}$ & 5 & 5 & 5 & 5 & 5 & 5 & 5 & 5 & 5 & 5 & 5 \\
\hline \multirow[t]{3}{*}{ NDMI } & $\begin{array}{l}\text { Pearson } \\
\text { Correlation }\end{array}$ & $\begin{array}{c}- \\
0.723\end{array}$ & $\begin{array}{c}- \\
0.774\end{array}$ & $\begin{array}{c}- \\
0.571\end{array}$ & $\begin{array}{c}- \\
0.571\end{array}$ & $\begin{array}{c}- \\
0.571\end{array}$ & $\begin{array}{c}- \\
0.388\end{array}$ & $\begin{array}{c}- \\
0.187\end{array}$ & $\begin{array}{c}- \\
0.753\end{array}$ & $\begin{array}{c}- \\
0.654\end{array}$ & $\begin{array}{c}- \\
0.606\end{array}$ & $\begin{array}{c}- \\
0.292\end{array}$ \\
\hline & $\begin{array}{l}\text { Sig. } \\
\text { (1tailed) }\end{array}$ & 0.084 & 0.062 & 0.157 & 0.157 & 0.157 & 0.260 & 0.381 & 0.071 & 0.116 & 0.139 & 0.317 \\
\hline & $\mathrm{N}$ & 5 & 5 & 5 & 5 & 5 & 5 & 5 & 5 & 5 & 5 & 5 \\
\hline \multirow[t]{3}{*}{ MNDWI } & $\begin{array}{l}\text { Pearson } \\
\text { Correlation }\end{array}$ & 0.181 & $\begin{array}{c}- \\
0.059\end{array}$ & $\begin{array}{c}- \\
0.237\end{array}$ & $\begin{array}{c}- \\
0.237\end{array}$ & $\begin{array}{c}- \\
0.237\end{array}$ & $\begin{array}{c}- \\
0.587\end{array}$ &. & 0.613 & 0.629 & 0.376 & 0.532 \\
\hline & $\begin{array}{l}\text { Sig. } \\
\text { (1tailed) }\end{array}$ & 0.385 & 0.462 & 0.351 & 0.351 & 0.351 & 0.149 & 0.017 & 0.136 & 0.128 & 0.266 & 0.178 \\
\hline & $\mathrm{N}$ & 5 & 5 & 5 & 5 & 5 & 5 & 5 & 5 & 5 & 5 & 5 \\
\hline
\end{tabular}

**. Correlation is significant at the 0.01 level (1-tailed).*. Correlation is significant at the 0.05 level (1tailed).

Table (9a): Models of WQPs and water index, for five stations (date: 4/FEB/2017)

\begin{tabular}{|c|l|c|}
\hline Parameters & \multicolumn{1}{|c|}{ Model } & $\mathbf{R}^{\mathbf{2}}$ \\
\hline \multirow{2}{*}{$\mathbf{P H}$} & $\mathrm{PH}=8.396+2.622 \mathrm{NDWI}-4.295 \mathrm{NDMI}$ & 0.752 \\
\hline \multirow{2}{*}{$\mathbf{C}$} & $\mathrm{CL}=153.835+18.353 \mathrm{AWEI}$ & 0.751 \\
\cline { 2 - 3 } & $\mathrm{CL}=133.327+18.030 \mathrm{WRI}+10.578 \mathrm{AWEI}$ & 0.830 \\
\cline { 2 - 3 } $\mathbf{S O}_{4}$ & $\mathrm{CL}=144.824+25.024 \mathrm{WRI}+44.690 \mathrm{AWEI}-78.621 \mathrm{MNDWI}$ & 0.918 \\
\hline \multirow{2}{*}{$\mathbf{N a}$} & $\mathrm{Sa}=$ =1433.507-2.500AWEI & 0.982 \\
\cline { 2 - 3 } & $\mathrm{Na}=143.293-4.819 \mathrm{AWEI}+4.908 \mathrm{MNDWI}$ & 0.915 \\
\hline $\mathbf{K}$ & $\mathrm{K}=3.053-2.068 \mathrm{AWEI}+3.365 \mathrm{MNDWI}$ & 0.820 \\
\hline
\end{tabular}


Table (9b): Models of WQPs and water index, for five stations (date: 11/MAY/2017)

\begin{tabular}{|c|l|c|}
\hline Parameters & \multicolumn{1}{|c|}{ Model } & $\mathbf{R}^{\mathbf{2}}$ \\
\hline \multirow{2}{*}{ PH } & $\mathrm{PH}=8.327-1.050 \mathrm{NDWI}$ & 0.678 \\
\cline { 2 - 3 } E.c & $\mathrm{PH}=8.197-4.321 \mathrm{NDWI}+3.061 \mathrm{NDMI}$ & 0.904 \\
\hline \multirow{2}{*}{$\mathbf{C L}$} & $\mathrm{E} . \mathrm{c}=837.273-183.706 \mathrm{NDWI}$ & 0.763 \\
\hline \multirow{2}{*}{$\mathbf{S O}_{\mathbf{4}}$} & $\mathrm{CL}=113.400-22.163 \mathrm{WRI}-8.024 \mathrm{AWEI}$ & 0.983 \\
\hline \multirow{2}{*}{$\mathbf{N a}$} & $\mathrm{SO}_{4}=216.278-71.909 \mathrm{MNDWI}$ & 0.712 \\
\cline { 2 - 3 } & $\mathrm{SO}_{4}=255.878-32.477 \mathrm{WRI}+14.521 \mathrm{AWEI}-96.632 \mathrm{MNDWI}$ & 0.821 \\
\hline \multirow{2}{*}{$\mathbf{K}$} & $\mathrm{Na}=68.266-62.126 \mathrm{NDWI}+39.756 \mathrm{MNDWI}$ & 0.856 \\
\hline & $\mathrm{Na}=60.495-244.237 \mathrm{NDWI}+172.750 \mathrm{NDMI}+53.981 \mathrm{MNDWI}$ & 0.974 \\
\hline
\end{tabular}

\section{الفيزيائية والكيميائية من خلال تطبيق الاستثعار عن بعد وتقنيات نظم المطومات الجغرافية}

الخلاصة: هذه الدراسة قد أجريت بواسطه تحليل البيانات من صورة القمر الصناعي (لاندسات-8 ) ونظام المعلومات

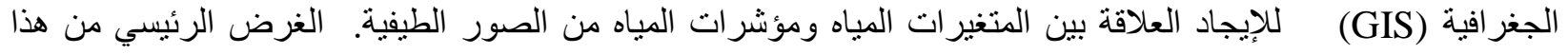

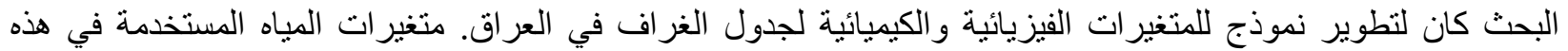

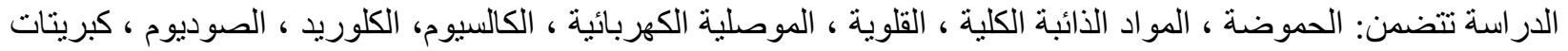

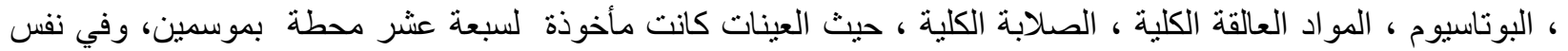

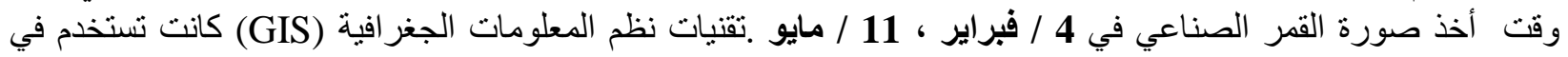

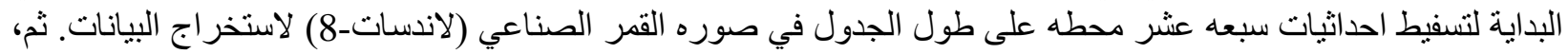

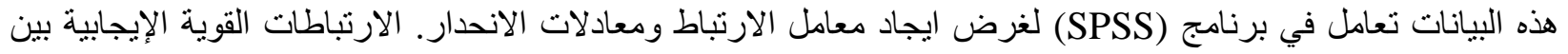

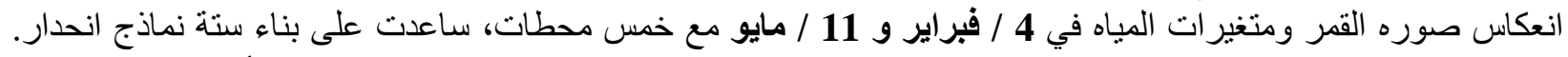

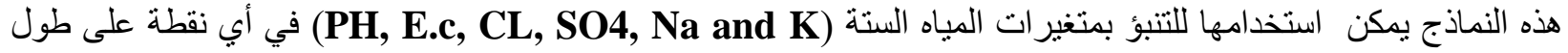
الجدول في العر اق من صوره القمر مباشرة.

\section{References}

[1] Usali, N., \& Ismail, M. H. (2010). USE OF REMOTE SENSING AND GIS IN MONITORING WATER QUALITY. Journal Of Sustainable Development, 3(3), 228.

[2] Panda, S.S., V. Garg, and I. Chaubey, (2004). ARTIFICIAL NEURAL NETWORK APPLICATION IN LAKE WATER QUALITY ESTIMATION USING SATELLITE IMAGERY. Journal of Environmental Informatics 4(2):65-74.

[3] AL-BAHRANI, H. S. (2014). SPATIAL PREDICTION AND CLASSIFICATION OF WATER QUALITY PARAMETERS FOR IRRIGATION USE IN THE EUPHRATES RIVER (IRAQ) USING GIS AND SATELLITE IMAGE ANALYSES. International Journal of Sustainable Development and Planning, 9(3), 389-399.

[4] Abdullah, H. S. (2015). WATER QUALITY ASSESSMENT FOR DOKAN LAKE USING LANDSAT 8 OLI SATELLITE IMAGES(Doctoral dissertation, University of Sulaimani).

[5] Al-Saadi, Hussain Ali, Najem Qamar Al-Daham and Leith Abdul Jalil Al-Hossan (1986). ENVIRONMENTAL SCIENCE. Dar Al Kutub Printing and Publishing University of Basra. 
[6] Alparslan, E., Aydöner, C., Tufekci, V., \& Tüfekci, H. (2007). WATER QUALITY ASSESSMENT AT ÖMERLI DAM USING REMOTE SENSING TECHNIQUES. Environmental Monitoring And Assessment, 135(1-3), 391.

[7] Zanter, K. (2005). LANDSAT 8 (L8) DATA USERS HANDBOOK. LSDS-1574 Version, 1.

[8] MCFEETERS, S.K., (1996), THE USE OF NORMALIZED DIFFERENCE WATER INDEX (NDWI) IN THE DELINEATION OF OPEN WATER FEATURES. International Journal of Remote Sensing, 17, pp. 1425-1432.

[9] Ko, B. C., Kim, H. H., \& Nam, J. Y. (2015). CLASSIFICATION OF POTENTIAL WATER BODIES USING LANDSAT 8 OLI AND A COMBINATION OF TWO BOOSTED RANDOM FOREST CLASSIFIERS. Sensors, 15(6), 13763-13777.

[10] Zhang, K., Thapa, B., Ross, M., \& Gann, D. (2016). REMOTE SENSING OF SEASONAL CHANGES AND DISTURBANCES IN MANGROVE FOREST: A CASE STUDY FROM SOUTH FLORIDA. Ecosphere, 7(6).

[11] Feyisa, G. L., Meilby, H., Fensholt, R., \& Proud, S. R. (2014). AUTOMATED WATER EXTRACTION INDEX: A NEW TECHNIQUE FOR SURFACE WATER MAPPING USING LANDSAT IMAGERY. Remote Sensing of Environment, 140, 23-35.

[12] Mukherjee, N. R., \& Samuel, C. (2016). ASSESSMENT OF THE TEMPORAL VARIATIONS OF SURFACE WATER BODIES IN AND AROUND CHENNAI USING LANDSAT IMAGERY. Indian Journal of Science and Technology, 9(18).

*Corresponding author.

E-mail address: sonlargeiraq@ yahoo.com 